\section{Stock Management in Public Libraries: recent and current research}

\section{Geoffrey Smith}

The stock is one of the key assets of public library services, fundamental to the delivery of their objectives, and its management is central to the effective management of public library authorities. The introduction of the UK Government's 'Best Value' initiative, part of its programme for modernising local government, involves the questioning of all policies and practices: it will mean further critical examination of stock management and an important research role.

In recent years there have been some studies of public library stock management, and in particular of the management of bookstocks, in which I have been involved. In them I have drawn on a wide experience:- managing Leicestershire Libraries and Information Service from 1963-1990; a director of T C Farries and Company Limited, Booksellers, from 1990-1994; member of the steering groups of earlier studies of stock management funded by the British National Bibliography Research Fund and carried out by Capital Planning Information (CPI); chairing CPI Policy Seminars at Stamford; and discussions at Loughborough University with the Library and Information Statistics Unit and with staff and students in the Department of Information Studies.

\section{In 1996 the Audit Commission awarded a} contract to Capital Planning Information to carry out research into stock management as part of their large and formal 'Value for Money' study of public library and information services. The Project Team (David Barton, Ron Pybus, Don Kennington, Jim Rowlands and myself) produced four reports for the Commission. These were not published but contributed to the Audit Commission's report, Due for Renewal ${ }^{2}$, published in 1997 and to the Commission's Audit Guide $^{3}$ - distributed to auditors in the following year as part of the external audit for 1998 which paid particular attention to library and information services. The Commission had intended to publish a further report giving guidance to library authorities in implementing best practice in stock management. But in the event this was subsumed into later work for 'Best Value' in library and information services.

\section{The Library Association and the National} Acquisitions Group were already considering the need for Guidelines for Public Library Stock Management, especially in the light of the findings of an Audit Commission survey that only half the library authorities had published stock management policies. Funding was sought from the British National Bibliography Research Fund. CPI was commissioned to build on the work for the Audit Commission and carry out a study of public library stock management - including the preparation of draft guidelines. In addition to drawing on the Audit Commission research we carried out desk research and visits and telephone discussions with many other libraries, groups and individuals.

This research defined stock as:

all materials provided by public library services, including books, grey literature, journals, reference publications, audio and video recordings, CD-ROMs, software, and access to electronic information

It defined the management of stock as:

a continuous process covering the range of interdependent activities required to make these materials an effective part of the resources required to deliver the public library service

Rather than attempting to provide specific guidance for the management of books, the guidelines were developed to deal with principles of stock management applicable to all media books, grey literature, journals, reference publications, audio and video recordings, $\mathrm{CD}$ ROMs, software, and access to electronic information. 
The report was published in $1998^{4}$ and disseminated in two well attended seminars.

Experience in the book trade and in libraries had led me to an interest in the processes of public library book selection and to publish a paper in 'Taking Stock's. Further work on the topic led to BNBRF funding a CPI study into 'Information used in Public Library Book Selection's. This involved a questionnaire survey seeking to identify both the information sources used and their relative importance, and also the types of information used by selectors and its importance. The results of the survey were complemented by discussions with the providers of the information sources - publishers, wholesalers, booksellers, and specialist information providers - and with librarians carrying out book selection. The report shows the diversity of sources used and the variety of approaches to book selection and its management; it gives an insight into the requirements of selectors and how far they are met by existing sources.

The research demonstrated the value and importance of discussing the context of book selection and the processes involved in order to share experience and good practice. It would appear that, apart from the seminars and conferences of the National Acquisitions Group, there are all too few opportunities for such discussion. Sharing experience and ideas in book selection is valuable: the report suggests that the relevant Groups and Branches of the Library Association could consider ways of fostering it. The research also shows that there would be considerable value in discussions between selectors in libraries and selectors in the book trade to share experience on information requirements and sources.

The report is set in the context of rapid changes in the UK book trade. The tradition of "territorial publishing rights' is under threat in the context of international Internet book selling. The implementation of the proposals on, for example, electronic trading and returns management in the KPMG Book Trade Supply Chain report will affect both libraries and their suppliers.
It is generally accepted that the return on investment in the library supply industry is derisory. The continuing reduction in the size of the UK public library market means that the overheads such as information collation and supply, stockholding, and development have to be met from turnover which is reducing in real terms. It is therefore unlikely that all the present library suppliers will remain independent and that there will be fewer responses to library book supply tenders.

The range of information sources available to selectors includes publishers' catalogues, advance information sheets, Publishing News, The Bookseller, suppliers lists and $5 \times 3$ slips, profiled lists from suppliers, suppliers recommendations, suppliers selections, visits to stockholding booksellers, visits to suppliers stockrooms, approval collections, profiled approval collections, recommended and evaluated lists. There is concern over the time needed to collate them to assist effective selection (even though so much of the examination of information from these sources is done outside work time).

Each source has its strengths and weaknesses and experience is giving rise to concerns over the electronic services offered by suppliers. The convergence of Book Data and Bibliographic Data Services may be the opportunity for a service more closely related to the needs of library selectors to be developed. If this takes place, the library suppliers could be relieved of the costs of providing selection information and libraries might secure better terms for book supply. The potential of the Internet as a communication medium for such a service is considerable now that the 'Peoples Network' is being developed. The present information services are not seen to cover specialist and minority needs in a way that is consistent and assured, and selectors are looking forward to joint services and other developments to meet these important needs.

Librarians are increasingly concerned over the whole cost of book selection - staff time, travelling costs, the costs of space etc. This is likely to increase the weighting given to the 
Stock Management in Public Libraries Geoffrey Smith

quality of selection information offered by library suppliers in evaluating their tenders for book supply.

There is a renewed interest in the involvement of suppliers in the selection process. Diminished bookfunds have changed the selection process: selectors indicated that some $80 \%$ of the titles selected and their allocation were 'inescapable'. Time spent on them could no longer be justified. Approaches that used the knowledge of suppliers to recommend what the library should buy - or to supply it within agreed selection and financial parameters - were worth consideration, if only to allow adequate time to be spent in the evaluation and selection of the other $20 \%$ of titles.

There is potential for assisting selection decisions by co-operative based use of specialist

knowledge. The use of the Internet to disseminate it would overcome the production costs that have made earlier approaches impracticable.

Earlier work on Stock Management called for joint approaches to library system suppliers to build in to library housekeeping systems the management and performance information required to assist in the selection and management of stock. This research has confirmed and emphasised the need. As booksellers and library suppliers develop their management information and decision support systems the contrast with public library systems becomes even greater.

In preparation for the CPI Stamford Seminar in 1996 following the demise of the Net Book Agreement ${ }^{1}$ I undertook a survey of UK public libraries to provide information on their experience of the new market conditions. One of the interesting findings ${ }^{7}$ was the extent of the involvement of booksellers and library suppliers in selecting books for public libraries. When Westminster City Libraries and Hertfordshire Libraries announced their intention to carry out six month pilot projects in which library suppliers would select the newly published books for libraries BNBRF agreed to fund a further CPI project to investigate the two projects and other examples of supplier selection in the UK and overseas. This work is in progress and involves
Library \& Information Research News (LIRN) Volume 23 - Number 73 - Spring 1999

discussions with the suppliers and the libraries to identify the reasons for the introduction of supplier selection, how it was developed and introduced, how it operated, how it was evaluated, and what lessons can be drawn from the their experience. The research and its findings should help library managers and their suppliers meet the challenges to traditional practice in book selection posed by the 'Best Value' regime in local government.

Concerns over the efficiency and effectiveness of the book supply chain, in particular its use of electronic information and trading, led the Publishers Association and the Booksellers Association to obtain funding for a study undertaken by $\mathrm{KPMG}^{8}$. This excluded library supply: but BIC and NAG subsequently secured BNBRF support for a study of the library supply chain - undertaken by Lindsey Muir and Frank Fishwick. This study is in progress and its report, expected later in 1999, will include an economic analysis of the library supply industry. Also expected in 1999 is the report of the Bournemouth University BLRIC/LIC funded investigation into consortia for the supply of materials and services.

Conclusion Those who hoped that the library supply industry would have stabilised in the years following the demise of the Net Book Agreement and Library Licence have been disappointed. As suppliers emerge offering new services or supply on new terms (or both), many traditional assumptions are being questioned.

Besides examining these changes and their implications more study is needed into the selection, acquisition and management of materials other than books in public libraries. Best practice needs to be shared if 'Best Value' is to be secured in the management of one of the principal assets of public libraries. Work in the United States on the library book market - through collaboration between the American Association of Publishers and the American Library Association - produced reports in 1975, 1987 and one to be published in 1999. There is no comparable survey for the UK and replication of the survey could provide a valuable context for future studies of the trade. 


\section{References}

I CPI. The impact of de-regulation on library supply: proceedings of a seminar held at Stamford, Lincolnshire on 3rd December 1996. CPI 1997

2 Audit Commission. Due for renewal: a report on the library service. Audit Commission, September 1997

3 Audit Commission. Audit guide: libraries. Audit Commission, November 1997

4 National Acquisitions Group. Public Library Stock Management. NAG, 1998

5 Smith, G. "What do we want to know: some thoughts on information for book selection" in Taking Stock 5 (I) May 1996, p. 31-33

6 CPI.A matter of choice: information used in public library book selection. CPI, December 1998

7 Smith, G. "Public library purchasing without the Net Book Agreement and Library Licence" in Taking Stock 6 (1) May 1997, p. I - 7

8 KPMG. Supply Chain Challenge. BA and PA, 1998 